Article

\title{
Feminist Documentary Cinema as a Diffraction Apparatus: A Diffractive Reading of the Spanish Films, Cuidado, resbala and Yes, We Fuck!
}

\author{
Orianna Calderon-Sandoval *(i) and Adelina Sanchez-Espinosa \\ Research Centre for Women's and Gender Studies, University of Granada, 18071 Granada, Spain \\ * Correspondence: orianna@correo.ugr.es
}

Received: 25 April 2019; Accepted: 27 June 2019; Published: 2 July 2019

\begin{abstract}
Following Karen Barad's diffractive methodology, we encounter feminist documentary cinema as a diffraction apparatus: that is, as technologies that make part of the world intelligible to another part of the world in specific ways, by means of intra-actions between human and non-human agencies and objects of observation. We propose three analytical tools: materiality, emotionality, and performativity. In this article, we analyse two Spanish documentary films that render visible the potential of feminist documentary cinema for building alliances from and against precarity: Cuidado, resbala and Yes, We Fuck! Reading the insights and patterns raised in each case study through one another (i.e., diffractively), we discuss the intra-actions by which each of these films participates in co-creating the real. We end up describing three possible effects of feminist material-discursive practices in documentary cinema.
\end{abstract}

Keywords: Documentary; diffraction apparatus; diffractive reading; Cuidado, resbala; Yes, We Fuck!; Spanish cinema; materiality; emotionality; performativity

\section{Introduction}

This article explores Karen Barad's diffractive methodology (Barad 2007) as a bridge between feminist documentary cinema and new materialist perspectives. ${ }^{1}$ We argue that feminist documentary films can be productively encountered as diffraction apparatuses: that is, as technologies that make part of the world intelligible to another part of the world in specific ways, by means of intra-actions between human and non-human agencies and objects of observation.

As a visualisation metaphor opposed to reflection, diffraction changes the focus from mirroring and sameness to attending "patterns of difference" (Barad 2007, p. 29), and "effects of difference" (Haraway [1992] 2004, p. 70). Such an onto-epistemological turn has ethico-political effects, as it moves from "reflecting on representations" to "accounting for how practices matter" (Barad 2007, p. 90). Moving away from the representational paradigm in the analysis of documentary cinema has an ethical impact, changing the focus "from producing accurate and authentic representations to creatively contributing to the transformability of actual beings in the real" (Hongisto 2015, p. 12). ${ }^{2}$

1 In her PhD thesis, co-supervised by Adelina Sánchez-Espinosa, Beatriz Revelles's employs diffractive methodology as a bridge between the Social Sciences and the Humanities (Revelles Benavente 2014, p. 75). Our article takes its inspiration from this proposal.

2 For a comprehensive revision of the concept of social representation, see Rubira García et al. (2018). It could be productive to read Barad's diffractive methodology through Serge Moscovici's theory of social representations, particularly due to his understanding of representation not as reproduction, but as a re-production, i.e., a new production of meaning "born from the interactions between the subjects (at all levels, including individual, group, institution, or at a massive scale) and the object itself" (Rubira García et al. 2018, p. 3). His approach blurs the separation between object and subject, focusing instead 
Most of the first independent films made by feminist activists in the seventies belong to the realist documentary film tradition. ${ }^{3}$ Documentaries such as Union Maids (Union Maids 1976) showed the lives of women outside the limited range of female images in classical cinema, which supports the argument that they displayed more "accurate" realities. However, feminist theorists like Claire Johnston soon began to challenge realistic aesthetics. She argues that realism maintains the delusion of classical cinema by pretending the non-intervention of the filmmakers limited, apparently, to showing reality as it is. The gaze of the camera is supposed to be innocent:

What the camera in fact grasps is the "natural" world of the dominant ideology. Women's cinema cannot afford such idealism; the "truth" of our oppression cannot be "captured" on celluloid with the "innocence" of the camera: it has to be constructed/manufactured. New meanings have to be created by disrupting the fabric of the male bourgeois cinema within the text of the film. (Johnston [1973] 2000, p. 29)

The clash of these two positions, realist documentary vs. counter-cinema ${ }^{4}$, leads to the so-called realist debate of the late seventies. Within feminist film theory, the debate increasingly begins to be in favour of anti-realism, thus distinguishing two successive moments in feminist film production: Firstly, an effort to change the content of dominant cinema, by means of portraying women talking about their "real" experiences; secondly, a growing interest in film form. Nevertheless, theorists such as Julia Lesage have refused the sharp rejection of cinematic realism and have questioned this apparent succession. The production of realist feminist documentaries has continued alongside more risky formal experiments, so that "both realist and experimental documentary forms have been politicized by feminist filmmakers" (Lesage 1984, p. 246).

We argue that the diffraction metaphor can move this debate forward by accounting for how material-discursive practices in feminist filmmaking matter. We agree with Ilona Hongisto's affirmation that "documentaries do not only operate on a plane of signification, but also partake in the material processes that co-compose the real" (Hongisto 2015, p. 12). For her, the main way in which politically committed documentary films participate in "the real as process" (Hongisto 2015, p. 12) is through framing, which involves making cuts and drawing boundaries within phenomena. That is also what diffraction apparatuses do.

This article is divided into four sections. The first section introduces diffractive methodology as a reading strategy and as a visualisation metaphor and develops our conceptualisation of feminist documentary cinema as a diffraction apparatus. In the second section, we discuss the potential of feminist documentary cinema for building alliances from and against precarity, the framework in which we locate our two case studies, i.e., Spanish documentary films Cuidado, resbala (2013) and Yes, We Fuck! (2015). These are diffractively read in the third section. In the last section, we describe three possible effects of feminist material-discursive practices in documentary cinema by reading through one another (i.e., diffractively) insights and patterns raised in each case study.

on the interactions which, for Barad, are more accurately described as intra-actions, as explained in the next section. Like Barad, Moscovici resorts to quantum-physics inspired metaphors to explain the active role of representations in co-creating the real: "Here and there we find a tendency to consider that social representations are the inner reflection of something external, the surface and ephemeral layer of something deeper and more permanent. While everything points to see in them a constitutive factor of social reality, just as invisible particles and fields are a constitutive factor of physical reality" (Rubira García et al. 2018, p. 3).

3 Realism in cinema is characterised by representations that "present an appearance of transparency by effacing the processes of meaning production in their own textual operations." (Kuhn 1994, p. 151).

4 Peter Wollen coined the term "counter-cinema" in 1972. The features of this type of cinema are, according to Wollen, those that oppose the characteristics of mainstream Hollywood productions, namely, "estrangement", "narrative intransitivity", "aperture" and "unpleasure", among others (Wollen [1972] 2002). It is a year after, in 1973 that Claire Johnston talks about feminist cinema in terms of counter-cinema. 


\section{From the Reflecting Mirror to the Diffraction Apparatus}

Diffraction is a concept used in physics to describe wave behaviour. As a quantum phenomenon, diffraction broke the paradigms of classical physics, since the double slit experiment ${ }^{5}$ proved that "the ontology of anything cannot be determined without regard to the apparatus of observation, or else that the apparatus participates in the ontology of the thing observed" (Belia 2015, p. 14).

In feminist theory, the metaphor of diffraction is employed to describe a critical consciousness that is attentive to differences and their effects. Donna Haraway asks us to consider what the physical phenomenon of diffraction could mean in onto-epistemological terms. She explains that, as a metaphor, diffraction "drops the metaphysics of identity and the metaphysics of representation and says optics is full of a whole other potent way of thinking about light, which is about history. It's not about identity as taxonomy, but it's about registering process on the recording screen" (Haraway 2000, pp. 103-4).

In accordance with this perspective, a documentary film would not be conceived as the reflection of any so-called fixed reality out there, which is then mirrored by the camera. Instead, it is analysed as technologies that co-produce and record the processes through which human elements (e.g., the filmmakers) and non-human elements (e.g., the camera) intra-act with other human and non-human parts of the world (e.g., filmed subjects and objects, spectators, screens).

Apart from the optical metaphor, Barad also employs diffraction to describe a reading methodology that attends to "entanglements in reading important insights and approaches through one another" (Barad 2007, p. 30). Within a diffractive approach, "any reading of texts is a meaning-making practice" (Belia 2015, p. 16). Rather than focus on accurate reflections of the world, diffractive reading engages in the re-making of the world. Birgit Kaiser defines diffractive reading as "radically performative" (Kaiser 2014, p. 281): it is by reading texts together that certain patterns emerge, so that reading in itself becomes a productive event.

The separation between subject/observer and object/observed is replaced by an understanding that both are permanently entangled. Diffraction does not take the boundaries of any subject nor object for granted, "but rather investigates the material-discursive boundary-making practices that produce 'objects' and 'subjects' and other differences out of, and in terms of, a changing relationality" (Barad 2007, p. 93). Rather than "interactions", Barad talks about "intra-actions" to highlight the fact that objects and agencies of observation are mutually constituted in their encounters.

To conceive feminist documentary films as diffraction apparatuses that "enact what matters and what is excluded from mattering" (Barad 2007, p. 148) from a gender-aware perspective involves analysing how the films intra-act with different parts of the world, the differences they make, and where the effects of those differences appear. This means reading them as entangled with their filmmakers' positions, the production decisions surrounding them, and their reception effects.

We propose three tools for analysing documentary cinema as a diffraction apparatus: materiality, emotionality and performativity. Materiality is a term borrowed from Domitilla Olivieri's PhD thesis, in which she uses the expression "materiality of documentary" to describe two aspects. Firstly, she argues for "the filmic representation in its material specificity" (Olivieri 2012, p. 42), which involves going beyond the content (i.e., narrative structures, plot and subject matter), and paying attention to "how the film is constructed: its technologies, framing, editing, voice-over, use of realistic or fictional images and sounds, and use of different filmic strategies" (Olivieri 2012, p. 10). Secondly, materiality "refers to the manner in which documentary film engages with bodies and with the matter of the world" (Olivieri 2012, p. 10).

Thomas Young performed the double-slit experiment with light in 1801. In 1927, Davisson and Germer demonstrated that electrons show the same behaviour: "The Davisson-Germer experiment showed that under some circumstances, matter (in this case electrons) exhibits wavelike behavior. Since the Davisson and Germer experiment, many other experiments have confirmed this result for other kinds of matter as well. That is, there is direct empirical evidence that matter-not just light—manifests wave behavior under the right experimental circumstances." (Barad 2007, p. 83). 
The second tool, performativity, is understood in four senses following Nichols (2010); Bruzzi (2000); Butler (1990, 2015) and Barad (2007). For Bill Nichols, the performative is one of the six possible modes of representation in documentary cinema. ${ }^{6}$ This mode emphasises the subjective dimensions of our knowledge of the world by stressing "the emotional complexity of experience from the perspective of the filmmaker him- or herself" (Nichols 2010, p. 202). Information and facts yield to "an expressive quality that affirms the highly situated, embodied, and vividly personal perspective of specific subjects" (Nichols 2010, p. 203). It is less concerned with formal experimentation in itself and, despite the centrality it gives to personal experience, it always joins "the particular to the general, the individual to the collective, and the personal to the political" (Nichols 2010, p. 204).

Some critics, however, claim that documentary cinema is always a performative act, regardless of its mode of representation. Stella Bruzzi, for instance, argues that documentaries are "the result of the intrusion of the filmmaker onto the situation being filmed" (Bruzzi 2000, p. 8). This, she continues, does not invalidate the authenticity of documentary. Rather, in her opinion, the idea of unmediated transparency is replaced "with a performative exchange between subjects, filmmakers/apparatus and spectators" (Bruzzi 2000, p. 6). Instead of presenting a reality that exists previously and independently, performative documentary cinema shows realities resulting from the intervention of the camera and/or the film production, situations created from the very action of making a documentary film. This definition of documentary as a performative act that captures some sort of reality in-the-making echoes Barad's understanding of reality as "an ongoing dynamic of intra-activity" (Barad 2007, p. 206).

Judith Butler first looked at the concept of performativity through feminist lenses in her 1990 book Gender Trouble. Feminism and the Subversion of identity. The concept of performativity originally refers to linguistic utterances that bring what they state into being or make a set of events happen as a consequence of the utterance being made. In Butler's words: "performativity is a way of naming a power language has to bring about a new situation or to set into motion a set of effects" (Butler 2015, p. 28). Paraphrasing her, we would like to propose performativity as a way of naming the power of documentary cinema "to bring about a new situation or to set into motion a set of effects" (Butler 2015, p. 28).

A new materialist reading of Butler's performativity has been elaborated by Mónica Cano (Cano Abadía 2017). She argues that Butler replaces the humanist subject with a vulnerable, interdependent subject who is open to change and to the constitutive relationship with others (Cano Abadía 2017, p. 266). We agree with her on this aspect, which is further developed in the next section. Cano also states that Butler does not reduce matter to language, nor does she enclose the subjects in a rigid socio-linguistic mechanism that produces them in a deterministic way (Cano Abadía 2017, p. 269).

What we want to emphasise from Barad's take on performativity is precisely the relevance she gives to matter: "an agential realist elaboration of performativity allows matter its due as an active participant in the world's becoming, in its ongoing intra-activity" (Barad 2007, p. 136). Hence, the performativity of documentary cinema as a diffraction apparatus, which includes human and non-human agents and objects of observation, matters at various levels: from the way it frames and creates boundaries, to the alliances it helps sustain on both sides of the camera and the screen.

Our third tool, emotionality, describes "how texts are 'moving', or how they generate effects (...) [and] the way in which texts name or perform different emotions" (Ahmed 2014, p. 13). Sara Ahmed is explicit about why she decides to employ the word "emotion" rather than "affect": "I was interested in this idea of movement that is explicit in its etymology. And it was also partly that I wanted to use the word that is used in everyday life" (Ahmed 2014, p. 97). She explains the connection between emotions and the making of boundaries:

6 The other modes are: expository, observational, participatory, poetic and reflexive. 
... it is through emotions, or how we respond to objects and others, that surfaces or boundaries are made: the "I" and the "we" are shaped by, and even take the shape of, contact with others (...) the surfaces of bodies "surface" as an effect of the impressions left by others (... ) emotions are not "in" either the individual or the social, but produce the very surfaces and boundaries that allow the individual and the social to be delineated as if they are objects. (Ahmed 2014, p. 10)

In this sense, we look for the emotions evoked by each film: how making and/or watching these films affect(s) subjects and objects on both sides of the camera and the screen. We conceive emotions as "effects rather than origins" (Ahmed 2014, p. 196).

Diffraction, therefore, is a multi-layered concept which we apply in this article in two different manners: one, we argue that any documentary film can be analysed as a diffraction apparatus that makes the world intelligible in specific ways and participates in co-creating the real; two, we diffractively read the insights raised by two case studies so as to identify effects of feminist material-discursive practices in documentary cinema.

\section{Feminist Cinema: Visualising Alliances from and against Precarity}

It is not our purpose in this article to look for an essentialist and prescriptive definition of what feminist documentary cinema is or should be. Instead, we follow Olivieri's proposal of "studying what makes a documentary feminist in terms of what a documentary does" (Olivieri 2012, p. 7). Therefore, we focus on the actual exploration and construction of contents, textual structures, formal strategies and means of production, distribution and exhibition which reveal a feminist consciousness, i.e., an awareness of the role that gender has (had) in the organisation and legitimisation of social inequalities.

Feminist documentary cinema can be understood as a form of countervisuality ${ }^{7}$, balancing between a lived reality of gender inequalities and imagined alternatives to it. The androcentric regime of gender visuality has been built around the subject of humanism: He is the norm according to which the racialised, sexualised and naturalised others are produced (Cano Abadía 2017, p. 265). What Cano explains is that Butler's theory of gender performativity has opened up a different understanding of subjects, starting from the recognition of their fundamentally interdependent and vulnerable condition.

The fact that we have to cohabitate with other humans and non-humans on which our lives depend, should make us "understand a global obligation imposed upon us to find political and economic forms that minimise precarity and establish economic political equality" (Butler 2015, pp. 121-22). Vulnerability is not inherent to a particular group, but unequally distributed as an effect of power relations under specific conditions. When this is not acknowledged, vulnerability can be used by political discourses as a way to produce and naturalise forms of social inequality.

In feminist theory, it has been argued that women face social vulnerability in a disproportionate way. What Butler warns against is the idea that "women have an unchanging and defining vulnerability" (Butler 2015, p. 140). Rather, she underlines that conditions such as poverty and illiteracy faced mainly by women are caused by an unequal distribution of precariousness fostered by gender power relations and lack of adequate socio-political infrastructures. She also states that women are "at once vulnerable and capable of resistance, and that vulnerability and resistance can, and do, and even must happen at the same time" (Butler 2015, p. 141).

To think about inequality in terms of precarity opens up the possibility for strategic alliances among different groups. In Butler's words: "precarity is the rubric that brings together women, queers, transgender people, the poor, the differently abled, and the stateless, but also religious and racial minorities: it is a social and economic condition, but not an identity" (Butler 2015, p. 58). When various minorities, whose alliance potential stems from their shared precarity, assemble in the streets and/or

7 "Countervisuality" is a concept coined by Nicholas Mirzoeff to refer to a resistant vision structured around the tension between the "need to apprehend and counter a real that does exist but should not, and one that should exist but is as yet becoming" (Mirzoeff 2011, p. 477). 
appear together in a media platform to demand their rights, they "enact another idea of equality, freedom and justice than the one that they oppose" (Butler 2015, p. 52).

The two documentary films that we have chosen as case studies render visible this kind of alliance. Cuidado, resbala is a collective film developed within a feminist economics framework that (re)positions care labour at the centre of the economic activities. Yes, We Fuck! is a postporn transfeminist film, which shows sexually explicit images that seek to question mainstream ideals of desirability, as well as sexual practices framed by ableism and heteropatriarchy. In the next section, we apply the previously described tools (materiality, performativity and emotionality) by tracing overlapping waves, patterns of differences and their effects. This is attained by reading the two documentary films through one another. Both films have been cut into four levels: form, content, production and reception. In order to analyse form and content, we carry out a feminist close reading (Lukic and Sánchez-Espinosa 2011). As for production and reception, the methods have been interviews with filmmakers and fieldwork at screenings.

\section{A Diffractive Reading of Cuidado, resbala ${ }^{8}$ and Yes, We Fuck!}

The title of the 2013 documentary film Cuidado, resbala plays with the two meanings of the word "cuidado" in Spanish, so that it can be roughly translated as Caution/Care Slippery. It is directed by two psychologists, a pedagogue, a lawyer, a teacher and a filmmaker (María Camacho Gómez, Montserrat Clos Fabuel, Mercedes Cordero Suárez, Vanessa Gómez Martínez, Carolina Suárez Rasmussen and Leonor Jiménez Moreno) from two feminist associations based in Málaga, Spain.

Sexuality and functional diversity ${ }^{9}$ are at the core of Yes We Fuck!, a postporn documentary film directed by two Spanish cismen ${ }^{10}$, Antonio Centeno and Raúl de la Morena. Postporn cinema "uses sexually explicit imagery to contest and complicate dominant representations of gender, sexuality, race, ethnicity, class, ability, age, body type, and other identity markers" (Miller-Young et al. 2013, p. 9). According to Centeno, "what postporn tries to do is to take the visual language of the ordinary porn, which greatly shapes our idea of what sexuality is, and turn it around, politicise it and turn those who were objects into subjects who can express their own pleasure, their own desire."11

Materiality, as explained above, pays attention to "how the film is constructed" and how it "engages with bodies and with the matter of the world" (Olivieri 2012, p. 10). For Hongisto, the main way in which politically committed documentary films participate in "the real as process" (Hongisto 2015, p. 12) is through framing. Taking Hongisto's question as a starting point, we intend to answer the following questions: How do our two case studies (re)frame reality? How do they entangle diverse narrative waves through the editing?

Cuidado, resbala exposes the discrimination encountered by domestic workers within an economics framework that places care labour in the hidden part of the iceberg sustaining the markets. Following Bill Nichols's typology of modes of representation in documentary cinema (2010), we can describe it as an observational-participatory documentary film, with a couple of expository animated sequences, and a reflexive performative voice-over that opens and closes the film. We identify four different narrative waves: voices of domestic workers; interviews with academic experts; animation; and reflexive voice-over. Through a diffractive lens, we can visualise how these waves overlap within the

8 A shorter version of the analysis of this film has been published in Feminist Media Studies (Calderón 2017).

9 Replacing the term "disability" with that of "functional diversity" has been put forward in Spain by the "Movimiento Vida Independiente" (Independent Life Movement), which is articulated through a virtual community called "Foro de Vida Independiente" (Independent Life Forum), founded in 2001.

10 The term cisgender, as opposed to transgender, refers to those people whose gender identity matches the sex that they were assigned at birth.

11 "El postporno lo que intenta hacer es coger el lenguaje visual del porno corriente que tanto configura nuestra idea de lo que es la sexualidad, y darle la vuelta, politizarlo y aquéllos que eran objetos, convertirlos en sujetos que enuncian su propio placer, su propio deseo." Antonio Centeno. Q\&A session. 5 November 2016 in Granada. All translations in this article are ours. 
film editing, hence revealing that the diverse and apparently disconnected insights on care labour are actually entangled. This strategy allows us to place at the same level two narrative waves: the voices of the domestic workers and the voices of the academic experts interviewed for the film (Amaia Pérez Orozco, Yayo Herrero, and Mercedes Cordero). Knowledge is thus produced in a horizontal way, entangling insights from personal experience with those from academic backgrounds.

A third wave is visualised with the animated sequence in which a female voice-over explains the intersections of gender, class and nationality in the global care chain: women from the Global South that have migrated to the Global North are being exploited as domestic workers, so that women from the so-called first countries can conciliate their professions with household chores. Neither men, nor industries, nor the State assume any responsibility for care labour. Some care services are privatised, but as a whole, this only aggravates inequalities. The reflexive performative voice over belongs to Carolina Suárez Rasmussen, one of the film directors and a migrant from Argentina who worked as a domestic worker in Spain for three years.

The opening and closing sequences of the film with the reflexive voice over constitute a fourth narrative wave. The film starts with Suárez Rasmussen's testimony about finding out that domestic labour does not have the same legal status as other jobs, and finishes with her account of how the personal conflicts she has faced are connected with that fact, and thus have a collective political dimension. This testimony is key for reading Cuidado, resbala as a research journey, and what she is looking for is exactly what diffraction focuses on, i.e., "how different differences get made" (Barad 2007, p. 30). Throughout the film, the viewer is encouraged to recognise the way in which care labour is rendered invisible, labelled as different from other jobs within the patriarchal and neoliberal socio-economic system, placing the responsibility for life care on individuals, mainly women. These sequences also have the peculiarity of raising awareness of the camera, making it felt as embodied from a specific gaze. Such formal strategy subverts the conventional understanding of an objective gaze in documentary cinema. Moreover, the opening sequence asks the spectator to identify with the point of view of a female illegal immigrant who works as a domestic worker, a subject which de-centers masculinity and whiteness.

In Yes, We Fuck!, the representation of the rebellious and diverse bodies of the filmed subjects questions pathology, monstrosity, voyeuristic curiosity and/or pitiful solidarity. Instead, the filmed subjects are presented as both, desiring and desirable through the intra-actions which take place both sides of the camera. The film consists of six ten-minute stories which could be analysed, we propose, as different narrative waves which provide spectators with diverse entry points. We listen to the filmed subjects' discourses but we also observe their practices, engaging in various sexual activities that fall out of what Gayle Rubin calls the "charmed circle of sex" (Rubin [1984] 2006, p. 153). ${ }^{12}$ Not only do their bodies deviate from ableist, racist and heterosexist norms but their sexualities also question androcentric, heteronormative and patriarchal conventions.

Yes, We Fuck! is a realist film whose main modes of representation are observational and participatory, though it also incorporates a performative mode in two of its stories. The first story works as a fist narrative wave in its setting the potential alliance between functional diversity and queer activists, stemming from the fact that their bodies do not fit within the productive norms. During a postporn workshop sequence, the observational-participatory mode of representation is combined with a poetic voice over which accompanies the images of group sex, in which sexualisation goes beyond the genitals and incorporates intra-actions between human and non-human artefacts. Centeno

12 Rubin explains that, in western heteronormative societies, sex is regulated by a sexual value system. Within the charmed circle of so-called good and natural sexuality we find that which is "heterosexual, marital, monogamous, reproductive, and non-commercial." Moreover, "it should be coupled, relational, within the same generation, and occur at home. It should not involve pornography, fetish objects, sex toys of any sort, or roles other than male and female. Any sex that violates these rules is 'bad', 'abnormal', or 'unnatural'." (Rubin [1984] 2006, p. 152). 
participates in the workshop, while the intra-actions between De La Morena and his camera with the rest of the bodies are expressed in very close shots, getting out of focus several times.

The second story presents a second wave by focusing on a heterosexual couple traversed by two visible differences: the functional diversity of Miriam, paraplegic, and the nationality of Pama, a migrant from India. The main mode of representation in this story is the observational-participatory one. In the interview with the couple, Pama hardly speaks and shows difficulty in communicating in Spanish. While she has an elaborated political discourse on sexuality and diversity, he uses very short phrases. What she emphasises is that due to his different cultural background, his gaze towards her is different, which she finds surprising. Since the story only lasts ten minutes, the characters' profiles and their relationship dynamics remain on a superficial level. The last scene, in which they have sexual intercourse, could be regarded as voyeuristic were it not for the fact that, within this story and in the film as a whole, the camera's voyeuristic gaze is constantly questioned (this is clear, for example, in stories four and six).

The third story also has an observational-participatory mode of representation. As a third narrative wave, it shows a BDSM session between a sex worker and a man with cerebral palsy. The fact that Linda is a female sex worker filmed by a man, wearing clothes associated with the figure of the dominatrix in mainstream porn, renders these sequences problematic, as they reproduce an objectifying and fetishistic gaze. ${ }^{13}$ There's, however, a counterbalance that has to be taken into consideration. Linda is also presented with close-ups of her face as she expresses her reasons for being a sex worker. It's important to note that Linda is a migrant from the Global South, from a Latin American country. She states that the first reason why she is a sex worker is because of the money, and only later does she elaborate on her political position "advocating for the freedom of bodies, the freedom of pleasure and the freedom in doing as we please with our own bodies, without any moral or political mandate" (Min. 21:26). Thus, the film does not hide the fact that precarity in a sexist, racist and classist society is a decisive factor behind the exercise of sex work, but by rendering visible Linda's confident testimony, it also argues against the stigmatisation and victimisation of sex workers. Another aspect worth mentioning is the fact that before the BDSM session, the dialogue between the characters emphasises consent, vulnerability and respect.

The fourth story starts with a sequence in which the performative mode of representation propitiates identification with Mertxe, a blind woman who also appears in the first story. During the first three minutes, the screen is totally black as we listen to her talking to a friend about a squirting workshop. The screen goes black again at the end of the story, as we listen to female moans of pleasure. Thus, the formal strategies employed in this fourth narrative wave question the ocularcentrism of dominant cinema, giving an example of a haptic visuality ${ }^{14}$ that triggers physical memories of touch, smell and taste. The contrast between the images of one character's vagina with a speculum and his subsequent assertion in an interview, identifying "with the male gender" (Min. 34:53), provides an eloquent example of the film as a diffraction apparatus. In reading one sequence through the other, this cutting-together-apart ${ }^{15}$ strategy renders visible gender performativity, as we see the disconnection between the body and the gender enacted by the same person.

The fifth story consists mainly of talking heads. Therefore, its mode of representation is observational-participatory. The organisation of the sequence, which presents first the opinions of people with intellectual diversity (Down syndrome) and then the opinions of their parents, establishes a clear contrast between sexuality as pleasure on the one hand, and reproduction as responsibility,

13 According to Laura Mulvey (Mulvey [1975] 1988, p. 58), fetishism fragments the female character into fetish images, such as her legs or her high-heel shoes.

14 In haptic cinema, the scopophilic drive is replaced by the pleasure evoked by other senses, thus opening up a synaesthetic dimension.

15 Agential cuts, according to Barad, do not produce absolute separations, but an agential situated separability, "a 'holding together' of the disparate itself" (Barad 2012, p. 46). 
on the other. The story does not take sides, nor does it go deeper into problematic issues such as sterilisation, which is only superficially raised. What is emphasised in this fifth wave is the sexual desires of people with intellectual diversity together with the freedom and openness with which they talk about their own sexuality. In this sense, talking heads emerge as an empowering tool for people who express and affirm themselves in front of the camera.

The last story, sixth narrative wave, introduces the figure of the sexual assistant, which is different from the sex worker in the third story. The sexual assistant helps a person with functional diversity have access to her/his own body, without becoming herself/himself engaged in sexual intercourse. This story resorts to a performative mode of representation because the characters record themselves. Most of the sequence is shot from the sexual assistant's point of view (Teo) as he caresses the body of a quadriplegic woman. The beginning and the end of the sequence, where Teo removes and puts back on the lens cap, raises awareness of the camera, directly interpellating the audience before the credits start. The two characters look directly into the camera as they say why they are recording the video: "Visualising all of this is important. It is also important to help people with functional diversity discover it since we don't know that we can ask for it and that it is within our rights" (Min. 55:49). In each story, the characters make explicit their position as politically informed. In this case, the filmed subjects assert that making the film itself is their political/activist intervention.

None of the film characters fit within the androcentric norm, let alone within the mainstream pornography standards of desirable bodies. Female pleasure and gender performativity are also key issues: there are transgender characters in three out of the six stories, and female characters embrace and openly discuss their sexual pleasure. In general, gender is considered as oppressive, but also as something that can be questioned and subverted. Indeed, Yes, We Fuck! has become a tool for alliances between Spanish activist groups, which have been called "Alianzas Tullido-Transfeministas", i.e., Crip-Queer Alliances (García-Santesmases Fernández et al. 2017). ${ }^{16}$

Our second tool, performativity, is connected with this understanding of the production process of the films as a political action in itself and their becoming militant objects. In the previous section we described documentary as a performative act that captures some sort of reality in-the-making that results from the intervention of the camera and/or the film production. And paraphrasing Butler, we proposed performativity as a way of naming the power of documentary cinema, conceived not as representation but as apparatus, "to bring about a new situation or to set into motion a set of effects" (Butler 2015, p. 28).

Cuidado, resbala was conceived as political from the beginning, not only in terms of content, but also in its production process. For Leonor Jiménez, the only professional filmmaker out of the six directors, the assembly-like method they carried out was very different from what she had been taught at film school:

Because normally, within the world of documentary and audiovisual creation, a lot of emphasis is placed on the author's gaze, which is individual and hierarchical. That person has to have a gaze of their own. And we were proposing exactly the opposite. (Jiménez et al. 2017) ${ }^{17}$

Jiménez emphasises that their being a group of feminist women was indeed a difference that mattered and had effects on their way of working, especially in terms of power relations. The creation of an empathetic and trusting atmosphere was also a fundamental aspect during the recording of the interviews. Clear explanations about who they were, what the film was about and why they had

16 Transfeminism keeps on working with the political subject "women", but advocates for a subject of feminism that includes other subjectivities, in as much as gender and the biological differences employed in the legitimisation of social inequalities do not only oppress women but also all those who do not fit within androcentric norms, such as queer individuals and people with functional diversity.

17 "Porque normalmente desde el mundo así de la creación documental, audiovisual, hacen mucho hincapié en la mirada del autor o de la autora. Una mirada individual, el autor, jerárquica; esa persona tiene que tener una mirada propia. Y nosotras estábamos planteando todo lo contrario." Leonor Jiménez. Personal interview. 23 January 2017 in Málaga. 
contacted the person for an interview contributed to reduce, albeit a little, "the issue of the camera as an invasive power element"18. They remember that a turning point in the making of Cuidado, resbala took place after the distressing interview with two domestic workers from Nicaragua. That's when they decided they had to look for alternatives so as to move from the personal to the collective and to avoid focusing only on victimisation. With the women from "Territorio Doméstico" they saw these possibilities materialised.

The importance that the film gives to global care chains and to the experience of women immigrants was not something deliberately present in their agenda, but an issue that arose as undeniable evidence. As Carolina Suárez summarises it: "If we talk about vulnerabilities or unequal treatment, I think that here all three things come together: being a woman, a migrant, and a domestic worker." ${ }^{19}$ According to her, Cuidado, resbala is a feminist documentary because it "questions, criticises and highlights all the contradictions of the patriarchal system and its economic correlate, which is capitalism" (Jiménez et al. 2017) Jiménez reckons that the film can actually be called radically feminist, in the sense that it goes to the roots of placing care at the centre of the system.

The film official premiere was at the 16th edition of the Málaga Film Festival in 2013. Produced with public funds, it did not have any commercial distribution and they stopped sending it to festivals when they realised that it was being asked for by lots of associations, workshops and seminars, which, from their point of view, were the main exhibition spaces. That's why they decided to put it online for free. ${ }^{21}$ In a similar way to that in which second wave feminists employed documentary films as a militant tool, some of the domestic workers who appear in Cuidado, resbala have used it in diverse forums to raise awareness and empower people who experience similar situations. For instance, "Territorio Doméstico" has organised projections at the "Eskalera Karakola" feminist space in Madrid, with the purpose of rendering visible their demands.

In the case of Yes, We Fuck!, Centeno admits that it was thanks to the contribution of researcher and anthropologist Andrea García-Santesmases that he and De la Morena found out that there were people already working with diverse sexual representations in feminist postporn cinema. They had not thought about the gender axis when they started working on the project but as they moved forward, it became one of their main insights:

What has subsequently been the central and most powerful axis of the documentary is that the gender axis and the axis of functional diversity are the same axes practically. I mean, in the end, the structure of oppression is the same, isn't it? That attempt to justify social inequalities because of biological differences is a very old story and that is why the discourses are so parallel and so related. $\left(\right.$ Centeno 2016) ${ }^{22}$

The production process of the film, and later on, its exhibition have been spaces for the encounter of these activisms. Looking at Yes, We Fuck! as a diffraction apparatus, rather than as a reflecting mirror that reproduces the same elsewhere, we can argue that the various narrative waves through which the axes of gender, sexuality and functional diversity are co-constructed by Centeno and De La Morena produce, facilitate and solicit new ways of seeing the intersections and alliances between these three axes (Minh-ha 2005, p. 13).

18 "Eso de la cámara como elemento invasivo y de poder" Leonor Jiménez. Personal interview. 23 January 2017 in Málaga.

19 "Si hablamos de vulnerabilidades o de desigual trato, yo creo que ahí se juntan las tres cosas. Por ser mujer, por ser migrante, por ser empleada doméstica." Carolina Suárez. Personal interview. 23 January 2017 in Málaga.

21 Vimeo website. Date of access: 20 February 2019. https://vimeo.com/67552738.

22 "Lo que luego ha sido el eje central y potente del documental que es que, el eje de género y el eje de diversidad funcional son el mismo eje prácticamente, o sea, que al final la estructura de opresión es la misma, ¿no? Ese intento de, de intentar justificar las desigualdades sociales a partir de las diferencias biológicas es una historia muy vieja y que por eso los discursos son tan paralelos y tan afines." Antonio Centeno. Skype interview. 20 November 2016. 
It's important to mention that in the Spanish context, there's a strong feminist debate about the abolition of prostitution or its legalisation as sex work. ${ }^{23}$ Centeno is in favour of the latter and has defended sexual assistance as a right for people with functional diversity within the Spanish Independent Life Movement. In this regard he states that: "Those in favour of the abolition of prostitution can incorporate the reality of functional diversity into the process of constructing a general human sexuality that is rich and appreciative of difference, so as to eliminate the demand for sexual services beyond police repression" (Centeno Ortiz 2014, p. 109). ${ }^{24}$

We finally come to our last tool, i.e., emotionality. How does making/watching these films affect subjects and objects on both sides of the camera and the screen? How do emotions produce the surfaces and boundaries that delineate the individual and the social? (Ahmed 2014, p. 10).

As mentioned before, several testimonies in Cuidado, resbala evoke anger and distress. The opening and closing sequences, with the reflexive voice over and the embodied subjective camera, perform entrapment and despair. These feelings are strong when domestic workers find themselves isolated. The turning point comes with the movement from individual struggle towards organised collective action with the testimonies of the women from "Territorio Doméstico", the interviews with academic experts who envision alternatives, and the festive demonstrations. The main emotions evoked in the film and gathered by the audiences have to do with empowerment, hope, pride and solidarity.

Similarly, the film subjects and spectators of Yes, We Fuck! have praised the sex-positive tone of the film. Even though several testimonies evoke shame, anger and discomfort, the film performs mainly positive emotions such as pleasure, love, trust, freedom and curiosity. As in the case of Cuidado, resbala, positive emotions become stronger when the struggle becomes open and collective. For instance, Soledad Arnau, the main character of the story about sexual assistance and a feminist functional diversity activist, describes her experience in the film as very positive:

All the stories have enriched me a great deal, and of course mine, well, I would not change the experience I had for anything, what I felt in that screening. Because for me it was like a before and after. I think it's a beautiful way to learn to love oneself, to love oneself even more, if I already loved myself then even more, and also to love the body because in the end, I think it's impossible to love yourself if you do not love your body (... .) To have a body is not something problematic, I believe it is the most beautiful thing in the world to have a body and to be able to enjoy it. And fortunately the documentary is an example, it shows that bodies are enjoyable. (Arnau 2018) 25

To conservative, paternalistic, heteronormative and ableist material-discursive practices, the filmmakers and filmed subjects of Yes, We Fuck! respond with their performative right to appear as desiring and desirable subjects.

\section{Three Effects of Feminist Material-Discursive Practices in Documentary Cinema}

In this final section, we diffractively read insights raised by each of our case studies to illustrate three effects that feminist material-discursive practices in documentary cinema can have. The first effect is that both films operate as feminist countervisuality devices that reframe realities from a gender

23 Instances of this are the steps towards the abolition of prostitution taken recently by the Spanish socialist government and their contestation from sex workers associations, attempting to create a sex workers trade union.

24 “Quien esté por la abolición de la prostitución, puede incorporar la realidad de la diversidad funcional al proceso de construir una sexualidad humana general suficientemente rica y positivamente apreciadora de la diferencia como para eliminar la demanda de servicios sexuales más allá de la represión policial."

25 "Todas las historias me enriquecen muchísimo y desde luego la mía, bueno, no cambiaría por nada del mundo la vivencia que viví, que sentí en esa proyección. Porque para mí fue como un antes y un después. Yo creo que es una forma preciosa de aprender a quererse a una misma, a quererse más todavía, si ya me quería pues ahora más todavía, y bueno también a querer al cuerpo porque al final, creo que es imposible quererte si no te quieres el cuerpo ( ... ) realmente no es nada problemático, es lo más hermoso del mundo tener un cuerpo, creo yo y poder disfrutar de este cuerpo. Y afortunadamente el documental es un ejemplo de que los cuerpos son disfrutables." Soledad Arnau. Q\&A Session. 16 October 2018 at the University of Granada. 
aware perspective. A pattern that both films share is that the filmed subjects are empowered as they enact their right to appear as political subjects in the public space.

In Yes, We Fuck!, rebellious and diverse bodies are presented in a way that questions their intelligibility from the perspectives of pathology and/or pitiful paternalism. In their sexually explicit images, the filmed subjects enact their performative right to appear as both, desiring and desirable. In Cuidado, resbala, care labour is placed at the centre of the economic activities. The filmmakers render visible inequalities connected with three factors: being a woman, a migrant, and a domestic worker. But they also propose real alternatives, showing the organised collective struggles of domestic workers and reading these insights from personal activist experience through those from feminist academic experts.

The second effect of feminist material-discursive practices in these films is their rendering visible the ways in which patterns of difference are turned into and/or employed by structures of inequality. In Cuidado, resbala, this is approached within the framework of the sexual division of labour. In the animated sequence, a female voice-over explains the intersections of gender, class and nationality in the transnational care chain. In the case of Yes, We Fuck!, Centeno admitted that directing this film made him realise that the feminist struggle and the struggle of people with functional diversity have various aspects in common: from their political work with the body, to the critical dismantling of the attempt to justify social inequalities arguing biological differences.

The third effect of feminist material-discursive practices that we diffractively read in these films has to do with the move from "reflecting on representations" to "accounting for how practices matter" (Barad 2007, p. 90). The directors of Cuidado, resbala and Yes, We Fuck! envisioned the production process of both films as a political action in itself. In Cuidado, resbala, the directors render visible inequalities faced by domestic workers, but they also visualise other possibilities for liveable conditions. The film evokes anger and distress with various testimonies, but rather than victimisation and paralysis, awareness of injustice is portrayed as leading to collective struggles. The subjects in Yes, We Fuck! accepted to appear in the film because they shared an understanding of the need to create a different collective imaginary. Through the co-organisation of filmed workshops, the production process operated as a space for the encounter of queer and crip activisms that had been mostly disconnected until then and that have continued working together since.

If we recognise the onto-epistemological potential of documentaries to "co-compose the real" (Hongisto 2015, p. 12), we can envision their ethico-political impact in the opening up of possibilities for gender and world making otherwise. The processes of making and watching feminist documentary films can co-create spaces for breaking the silence about precarious situations and for collectively generating more livable conditions. The two films that we have referred to manage to find a paradoxical balance pointed out by Butler: The filmed subjects—domestic workers, people with functional diversity, transgender activists-are presented as "at once vulnerable and capable of resistance" (Butler 2015, p. 141). Films like Cuidado, resbala and Yes, We Fuck! exemplify the capability of looking back and beyond androcentric visuality regimes.

Author Contributions: Article conceptualization, O.C.-S. and A.S.-E.; interviews, O.C.-S.; methodology and primary analysis, O.C.-S. and A.S.-E.; original draft preparation, O.C.-S.; review and editing, O.C.-S. and A.S.-E.; supervision, A.S.-E.; project administration, project design and funding acquisition A.S.-E.

Funding: This work is part of GRACE Gender and Cultures of Equality in Europe, a European Union's Horizon 2020 research and innovation programme under the Marie Skłodowska-Curie grant agreement No. 675378. The research has been funded by this project. The GRACE Project is led by Suzanne Clisby at the University of Hull. Adelina Sánchez-Espinosa is Principal Investigator at the University of Granada.

Conflicts of Interest: The authors declare no conflict of interest. The funders had no role in the design of the study; in the collection, analyses, or interpretation of data; in the writing of the manuscript, or in the decision to publish the results. 


\section{References}

Ahmed, Sara. 2014. The Cultural Politics of Emotion, 2nd ed. Edinburgh: Edinburgh University Press.

Arnau, Soledad. 2018. Q\&A Session at the University of Granada. October 16.

Barad, Karen. 2007. Meeting the Universe Halfway: Quantum Physics and the Entanglement of Matter and Meaning. Durham and London: Duke University Press.

Barad, Karen. 2012. Nature's Queer Performativity. Kvinder, Køn og forskning/Women, Gender and Research 1: 25-53. [CrossRef]

Belia, Vasiliki. 2015. You can read your way out of this. A diffractive reading of Alison Bechdel's Are You My Mother? with Virginia Woolf and Adrienne Rich. Master's thesis, Universiteit Utrecht, Utrecht, The Netherlands. Available online: https://dspace.library.uu.nl/handle/1874/320655 (accessed on 18 April 2019).

Bruzzi, Stella. 2000. New Documentary: A Critical Introduction. London and New York: Routledge.

Butler, Judith. 1990. Gender Trouble: Feminism and the Subversion of Identity. New York and London: Routledge.

Butler, Judith. 2015. Notes Toward a Performative Theory of Assembly. Cambridge, Massachusetts and London: Harvard University Press.

Calderón, Orianna. 2017. Feminist documentary cinema as a diffraction apparatus for the visualisation of care labour: the Spanish collective film Cuidado, resbala (2013). Feminist Media Studies 17: 308-12. [CrossRef]

Cano Abadía, Mónica. 2017. Agencia crítica y desposesión. La actualidad de la pregunta por la libertad en Judith Butler. ISEGORÍA Revista de filosofía moral y política 56: 263-77. [CrossRef]

Centeno, Antonio. 2016. Skype interview. November 20.

Centeno Ortiz, Antonio. 2014. Simbolismos y alianzas para una revuelta de los cuerpos. Educació Social Revista d'Intervenció Socioeducativa 58: 101-18. Available online: https://www.raco.cat/index.php/EducacioSocial/ article/view/284939/372790 (accessed on 18 April 2019).

Cuidado, resbala. 2013. Directed by María Camacho Gómez, Montserrat Clos Fabuel, Mercedes Cordero Suárez, Vanessa Gómez Martínez, Carolina Suárez Rasmussen and Leonor Jiménez Moreno. Málaga: La Mirada Invertida and Círculo de Mujeres. Available online: https://vimeo.com/67552738 (accessed on 20 February 2019).

García-Santesmases Fernández, Andrea, Nuria Vergés Bosch, and Elisabet Almeda Samaranch. 2017. “From Alliance to Trust": Constructing Crip-Queer Intimacies. Journal of Gender Studies 26: 1-13. [CrossRef]

Haraway, Donna. 2004. The Promises of Monsters: A Regenerative Politics for Inappropriate/d Others. In The Haraway Reader. New York and London: Routledge, pp. 63-124. First published 1992.

Haraway, Donna. 2000. How Like a Leaf. An Interview with Thyrza Nichols Godeve. New York and Oxon: Routledge. Hongisto, Ilona. 2015. Soul of the Documentary. Framing, Expression, Ethics. Amsterdam: Amsterdam University Press. [CrossRef]

Jiménez, Leonor, Carolina Suárez, and Montserrat Clos. 2017. Personal interview. Málaga, January 23.

Johnston, Claire. 2000. Women's Cinema as Counter-cinema. In Feminism and Film. Edited by E. Ann Kaplan. Oxford: Oxford University Press, pp. 22-33. First published 1973.

Kaiser, Birgit Mara. 2014. Worlding CompLit: Diffractive Reading with Barad, Glissant and Nancy. Parallax 20: 274-87. [CrossRef]

Kuhn, Annette. 1994. Women's Pictures. Feminism and Cinema, 2nd ed. London: Verso.

Lesage, Julia. 1984. Feminist Documentary: Aesthetics and Politics. In Show us Life. Toward a History and Aesthetics of the Committed Documentary. Edited by Thomas Waugh. London: The Scarecrow Press, pp. 223-51.

Lukic, Jasmina, and Adelina Sánchez-Espinosa. 2011. Feminist Approaches to Close Reading. In Theories and Methodologies in Postgraduate Feminist Research. Researching Differently. Edited by Rosemarie Buikema, Gabrielle Griffin and Nina Lykke. London: Routledge, pp. 85-160.

Miller-Young, Mireille, Tristan Taormino, Celine Parreñas Shimizu, and Constance Penley. 2013. Introduction: The Politics of Producing Pleasure. In The Feminist Porn Book. The Politics of Producing Pleasure. Edited by Miller-Young Mireille, Tristan Taormino, Celine Parreñas Shimizu and Constance Penley. New York: The Feminist Press at the City University of New York, pp. 9-20.

Minh-ha, Trinh T. 2005. The Digital Film Event. New York: Routledge.

Mirzoeff, Nicholas. 2011. The Right to Look. Critical Inquiry 37: 473-96. [CrossRef]

Mulvey, Laura. 1988. Visual Pleasure and Narrative Cinema. In Feminism and Film Theory. Edited by Constance Penley. New York and London: Routledge, pp. 57-68. First published 1975. 
Nichols, Bill. 2010. Introduction to Documentary, 2nd ed. Bloomington: Indiana University Press.

Olivieri, Domitilla. 2012. Haunted by Reality. Toward a Feminist Study of Documentary Film: Indexicality, Vision and the Artifice. Ph.D. thesis, Universiteit Utrecht, Utrecht, The Netherlands. Available online: https://dspace.library.uu.nl/handle/1874/221965 (accessed on 18 April 2019).

Revelles Benavente, Beatriz. 2014. Literature, Gender and Communication in the Making: Understanding Toni Morrison's Work in the Information Society. Ph.D. thesis, Universitat Oberta de Catalunya, Barcelona, Spain. Available online: https://www.tdx.cat/handle/10803/306597?locale-attribute=en (accessed on 18 April 2019).

Rubin, Gayle. 2006. Thinking Sex: Notes for a Radical Theory of the Politics of Sexuality. In Culture, Society and Sexuality. Edited by Aggleton Peter and Richard Parker. New York and London: Routledge, pp. 143-78. First published 1984.

Rubira García, Rainer, Puebla Martínez Belén, and Gelado Marcos Roberto. 2018. Social Representations in Studying Information, Knowledge, and Mediations: A Critical Review. Social Sciences 7: 256. [CrossRef]

Union Maids. 1976. Directed by Jim Klein, Miles Mogulescu and Julia Reichert. Ohio: New Day Films.

Wollen, Peter. 2002. Godard and Counter-Cinema. Vent d'Est. In The European Cinema Reader. Edited by Catherine Fowler. London and New York: Routledge, pp. 74-82. First published 1972.

Yes, We Fuck!. 2015. Directed by Antonio Centeno and Raúl de la Morena. Barcelona: Centeno, De la Morena and crowdfunding. Available online: https://vimeo.com/123177395 (accessed on 20 February 2019).

(C) 2019 by the authors. Licensee MDPI, Basel, Switzerland. This article is an open access article distributed under the terms and conditions of the Creative Commons Attribution (CC BY) license (http://creativecommons.org/licenses/by/4.0/). 